\title{
JENIS-JENIS IKAN DI SUNGAI SAMBUJUR, KALIMANTAN SELATAN
}

\author{
Syamsul Bahri \\ Teknisi Litkayasa pada Balai Riset Perikanan Perairan Umum, Mariana-Palembang \\ Teregistrasi I tanggal: 23 Agustus 2006; Diterima setelah perbaikan tanggal: 16 Mei 2007; \\ Disetujui terbit tanggal: 30 April 2007
}

\section{PENDAHULUAN}

Sungai Barito merupakan salah satu sungai besar di Pulau Kalimantan. Sungai tersebut bagian hulunya terletak di Serawak Malaysia dan Kalimantan Tengah, sedangkan bagian hilir ataupun muaranya terletak di Propinsi Kalimantan Selatan (Laut Jawa). Menurut Welcome (1985), wilayah perairan sungai dibagi menjadi 2 bagian besar, yaitu perairan bagian rethron (hulu) dan potamon (hilir), sedangkan menurut Samuel et al. (2002), wilayah perairan sungai di bagi menjadi 3 , yaitu perairan daerah aliran sungai bagian hulu, tengah, dan hilir.

Sungai Sambujur terletak pada posisi S. $2^{\circ} .252^{\prime \prime}$ .183" . E.125․142" .213", merupakan anak Sungai Barito yang terletak di daerah aliran sungai bagian tengah. Daerah ini merupakan daerah rawa banjiran yang dipengaruhi oleh pasang surut air laut dan di sekitarnya banyak ditumbuhi oleh tegakkan tumbuhan air serta sebagian berupa rawa lebak. Perairan yang banyak terdapat hutan rawa mempunyai produksi perikanan tinggi.

Jenis ikan di sekitar perairan Sungai Sambujur terbagi menjadi 2 bagian besar, yaitu ikan putihan (ikan sungai) dan ikan hitam (ikan lebak). Jenis ikan putihan yang ada di Sungai Sambujur antara lain adalah ikan baung (Mystus nemurus), patin (Pangasius pangasius), dan bakut (Oxyoleotris marmorata), sedang jenis ikan lebak antara lain ikan haruan (Channa striata), sapat (Trichogaster pectoralis), dan biawan (Helostoma temminckii).

Tujuan pengamatan ini adalah untuk mendapatkan data dan informasi tentang jenis ikan yang terdapat di perairan Sungai Sambujur, Kalimantan Selatan.

\section{BAHAN DAN ALAT}

\section{Bahan dan Alat}

Bahan dan alat terdiri atas ikan contoh, kantong plastik, formalin $10 \%$, karet gelang, spidol, notebook, boldpoin, timbangan, dan dessecting set 1 unit.

\section{Metode}

Pengamatan dilakukan dengan survei lapangan di perairan Sungai Sambujur pada tahun 2004 (Gambar
1). Contoh ikan diperoleh dari hasil tangkapan nelayan yang telah ditentukan lokasinya secara purposive yang mewakili habitat rawa lebak, sungai dan hutan rawa, khususnya di tempat-tempat yang aktivitas penangkapan tinggi seperti di Desa Paminggir, Sapala, Pal Batu, dan Danau Panggang.

Pengambilan contoh dilakukan saat musim kemarau maupun penghujan. Saat musim kemarau dilakukan 2 kali pengambilan contoh pada bulan Juni dan Agustus, sedang saat musim penghujan dilakukan pengambilan contoh 2 kali pada bulan Oktober dan Desember.

Ikan-ikan yang didapat dikumpulkan, dan dicatat dalam buku lapangan, kemudian dimasukan ke dalam kantong plastik, diberi label yang berisi keterangan, tanggal, tempat (lokasi), dan nama daerah, dan diawetkan dengan formalin $10 \%$. Selanjutnya, ikan contoh dibawa ke Laboratorium Balai Riset Perikanan Perairan Umum, Mariana-Palembang. Identifikasi dilakukan berdasarkan pada buku identifikasi ikan dari Kottelat et al. (1993).

\section{HASIL BAHASAN}

\section{Musim Kemarau}

Saat musim kemarau pada umumnya, aktivitas penangkapan terbagi 2, yaitu saat air mulai surut dan saat sudah surut. Ikan-ikan besar banyak tertangkap pada saat air mulai surut daripada saat air surut. Sedangkan saat air surut ikan-ikan yang tertangkap berukuran kecil. Kalau didapat yang ukuran besar, ikan-ikan tersebut berasal dari di dalam lubuk ataupun lebung.

Saat air mulai surut pengaruh hujan sudah tidak ada, namun air di sungai cukup tinggi dengan kedalaman lebih kurang 1,5 m pada saat ini semua jenis alat tangkap baik yang aktif maupun alat yang tidak aktif dioperasionalkan semua. Nelayan melakukan penangkapan ikan di perairan sungai dahulu, sedang di perairan rawa lebak aktivitas penangkapan dilakukan pada saat air lebak turun ke sungai. Saat air mulai surut, ikan sungai yang banyak tertangkap pada umumnya dari berbagai jenis ikan, dari famili Bagridae (baung), Pangasidae (patin), Crustaceae (Macrobrachium rosenbergii), dan Osphronemidae (gurami, Osphnonemus goramy). 
Untuk jenis-jenis yang lain dapat dilihat pada Tabel 1.

Saat air surut aktivitas penangkapan terjadi di lebak. Alat tangkap yang dioperasikan adalah trap atau hampang batas (penjebak) dan ikan yang tertangkap adalah ikan-ikan besar seperti dari famili Channidae (haruan dan toman) dan Helostomatidae (biawan, papuyuh, dan sapat), (Tabel 1).

Saat air surut di perairan sungai jenis-jenis ikan yang banyak didapatkan, sebagian besar ikan hias antara lain dari famili Cobitidae; ikan belang (Botia macracanthus) dan ikan jono (Botia hymenophisa), famili Mastcembalidae: tilan (Mastacembelus unicolor) dan famili Notopteridae: pipih Notopterus chitala).

Saat air surut di perairan rawa lebak, jenis ikan yang tertangkap antara lain ikan-ikan dari famili Eliotridae: bakut, famili Clariidae: lele (Clarias melanoderma), famili Belontiidae: sepat (Trichogaster trichopterus), dan famili Channidae: kihung (Channa gachua).

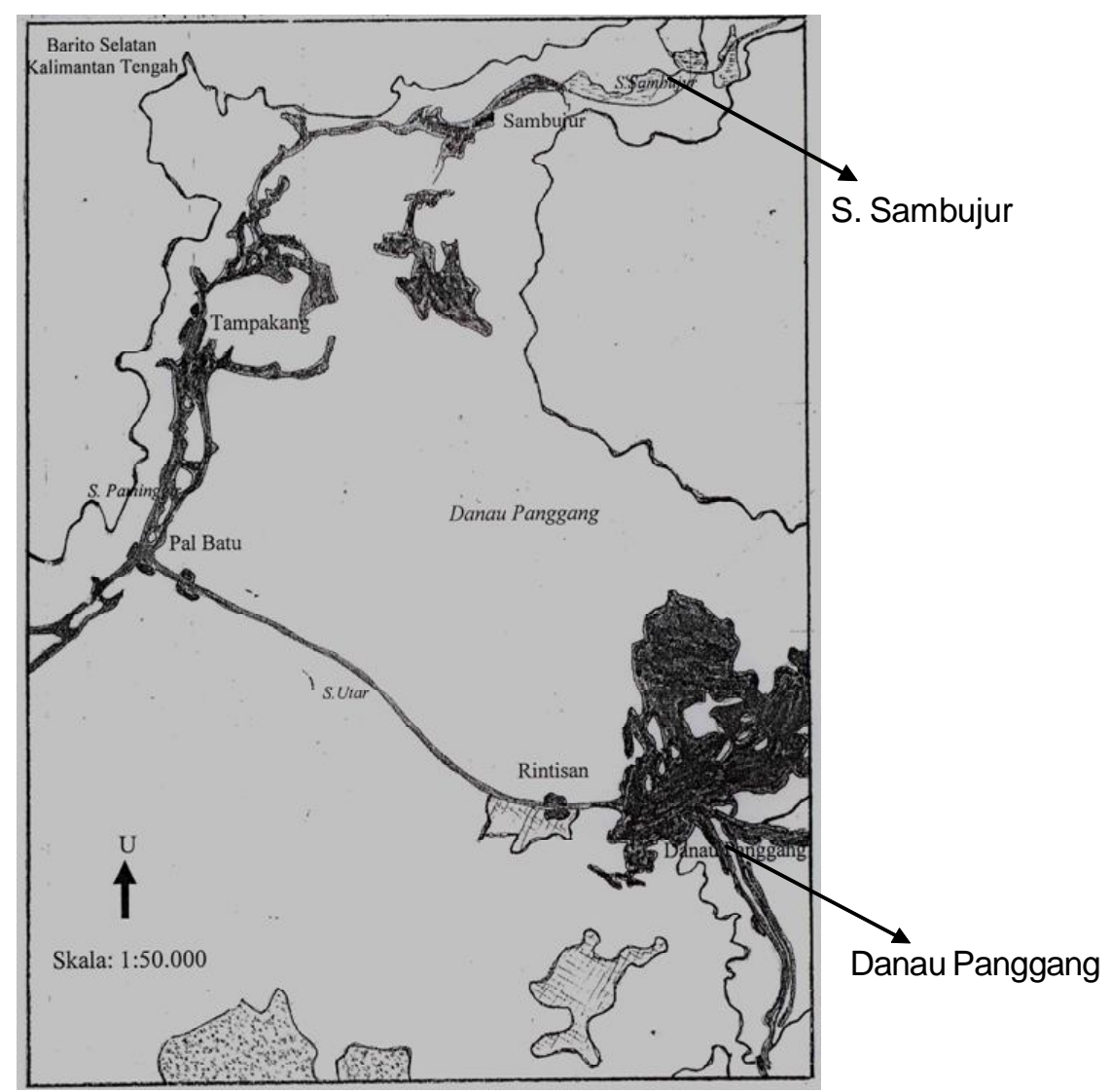

Gambar 1. Peta lokasi pengamatan jenis-jenis ikan di Sungai Sambujur, Kalimantan Selatan.

\section{Musim Penghujan}

Pada awal musim penghujan aktivitas penangkapan aktif baik di lebak mapun di sungai, setelah air mulai tinggi di atas permukaan sungai dan air masuk kadataran aktivitas penangkapan di sungai tidak dapat dilakukan lagi. Setelah air naik ke daratan aktivitas penangkapan beralih pada daratan yang tergenang air dan alat tangkap yang dapat dipergunakan jaring insang. Jenis ikan yang tertangkap jenis ikan lebak seperti ikan kihung, sepat, lele, haruan, toman (Channa micropeltas), biawan (Helostoma temminckii), dan papuyuh (Anabas testudineus).
Saat air mencapai ketinggian 2-3 $\mathrm{m}$ di atas permukaan daratan, nelayan tidak lagi mengoperasikan alat tangkap. Hal ini dikarenakan hampir semua jenis alat tangkap sudah tidak efektif lagi dioperasionalkan, karena semua perairan yang ada, bahkan daerah sekitar Sungai Sambujur tertutup oleh genangan air, sehingga aktivitas penangkapan tidak ada. Kalau ada nelayan yang menangkap menangkap benih, seperti benih ikan haruan, biawan, dan papuyuh. 
Tabel 1. Jenis-jenis ikan di Sungai Sambujur, Kalimantan Selatan

\begin{tabular}{|c|c|c|c|c|c|}
\hline \multirow{2}{*}{ No. } & \multirow{2}{*}{ Nama daerah } & \multirow{2}{*}{ Nama latin } & \multirow{2}{*}{ Famili } & \multicolumn{2}{|c|}{ Musim } \\
\hline & & & & Hujan & Kemarau \\
\hline 1. & Papuyuh & Anabas testudineus & Anabantidae & + & + \\
\hline 2. & Sapat siam & Trichogaster pectoralis & Belontiidae & + & + \\
\hline 3. & Sepat layang & Trichogaster leerii & Belontiidae & + & + \\
\hline 4. & Sepat merah & Trichogaster trichopterus & Belontiidae & + & + \\
\hline 5. & Kapar & Belontiia hasselti & Belontiidae & & + \\
\hline 6. & Tabiring & Walago belodontichthys & Batrachoididae & & + \\
\hline 7. & Panting & Mystus gulio & Bagridae & & + \\
\hline 8. & Baung & Mystus nemurus & Bagridae & & + \\
\hline 9. & Gunggut & Mystus wyekii & Bagridae & & + \\
\hline 10. & Beringit & Mystus nigriceps & Bagridae & & + \\
\hline 11. & Baung murai & Leiocassis stenomus & Bagridae & & + \\
\hline 12. & Baung bang & Leiocassis mahakamensis & Bagridae & & + \\
\hline 13. & Baung lilin & Mystus micracanthus & Bagridae & & + \\
\hline 14. & Bilis & Thynnichthys sp. & Cyprinidae & + & \\
\hline 15. & Sanggang & Punteoplites bulu & Cyprinidae & & + \\
\hline 16. & Puyau & Osteochilus hasseltii & Cyprinidae & & + \\
\hline 17. & Ganderia & Labiobarbus ocellatos & Cyprinidae & & + \\
\hline 19. & Seluang batang & Rasbora tawarensis & Cyprinidae & & + \\
\hline 20. & Jelawat batu & Labiobarbus kuhlii & Cyprinidae & & + \\
\hline 21. & Adungan & Hampala ampalung & Cyprinidae & & + \\
\hline 22. & Tembelikat & Osteochilus Microsephalus & Cyprinidae & & + \\
\hline 23. & Kelabau & Osteochilus kelabau & Cyprinidae & & + \\
\hline 24. & Sebaro & Hampala macrolepidota & Cyprinidae & & + \\
\hline 25. & Benangin & Thynnichthys polylepis & Cyprinidae & & + \\
\hline 26. & Bantak & Labiobarbus fistivus & Cyprinidae & + & + \\
\hline 27. & Puhing & Osteochilus intermedius & Cyprinidae & + & + \\
\hline 28. & Papirang & Parachela oxygastroides & Cyprinidae & & + \\
\hline 29. & Lampam & Barbodes schwanenfelldii & Cyprinidae & & + \\
\hline 30. & Juar & Luciosoma trenema & Cyprinidae & & + \\
\hline 31. & Belantau & Macrochirichthys macrochirus & Cyprinidae & & + \\
\hline 32. & Ikan salap & Puntius anchisporus & Cyprinidae & & + \\
\hline 33. & Kapas kapas & Rohteichthys microlepis & Cyprinidae & & + \\
\hline 34. & Sihitam & Labio chrysophekadion & Cyprinidae & & + \\
\hline 35. & Jelawat & Leptobarbus hoevenii & Cyprinidae & & + \\
\hline 36. & Mas besar & Albulichthys albuloides & Cyprinidae & & + \\
\hline 37. & Serpang & Puntioplthes waandersi & Cyprinidae & + & + \\
\hline 38. & Seluang api & Rasbora einthovenii & Cyprinidae & + & + \\
\hline 39. & Ikan belang & Botia macracanthus & Cobitidae & & + \\
\hline 40. & Jono & Botia hymenophysa & Cobitidae & & + \\
\hline 41. & Haruan & Channa striata & Channidae & + & + \\
\hline 42. & Toman & Channa micropeltes & Channidae & + & + \\
\hline 43. & Bujuk & Channa marulioides & Channidae & + & + \\
\hline 44. & Kihung & Channa gachua & Channidae & + & + \\
\hline 45. & Baga baga & Parambossis wolffii & Chandidae & & + \\
\hline 46. & Serandang & Channa pleurophthalmus & Channidae & + & + \\
\hline 47. & Lele panjang & Clarias meladerma & Clariidae & + & + \\
\hline 48. & Lele kecil & Clarias batrachus & Clariidae & + & + \\
\hline 49. & Pari air tawar & Hypolophus sephen & Dasyatidae & & + \\
\hline 50. & Bakut & Oxyeleotris marmorata & Eleotrididae & & + \\
\hline 51. & Biawan & Helostoma temminckii & Helostomatidae & + & + \\
\hline 52. & Julung-julung & Zenarchopterus buffonis & Hemiropidae & & + \\
\hline 53. & Tilan & Mastacembelus unicolor & Mastacembelidae & & + \\
\hline 54. & Tilan besar & Mastacembelus eryhtrotaenia & Mastacembelidae & & + \\
\hline
\end{tabular}


Tabel $1 . \quad$ Lanjutan

\begin{tabular}{|c|c|c|c|c|c|}
\hline \multirow{2}{*}{ No. } & \multirow{2}{*}{ Nama daerah } & \multirow{2}{*}{ Nama latin } & \multirow{2}{*}{ Famili } & \multicolumn{2}{|c|}{ Musim } \\
\hline & & & & Hujan & Kemarau \\
\hline 55. & Pipih/Belida & Chitala lopis & Notopteridae & & + \\
\hline 56. & Pipih/Putak & Notopterus notopterus & Notopteridae & & + \\
\hline 56. & Gurami & Osphronemus goramy & Osphronemidae & & + \\
\hline 57. & Tengklesa & Scleropages formosus & Osteoglassidae & & + \\
\hline 58. & Sepatung & Pristolepis fasciata & Prestolepididae & + & + \\
\hline 59. & Udang galah & Macrobrachium rosenbergii & Palaemonidae & & + \\
\hline 60. & Lawang & Pangasius polyuranodon & Pangasidae & & + \\
\hline 61. & Patin & Pangasius humealris & Pangasidae & & + \\
\hline 62. & Ikan sebelah & Achirus poropterus & Soleidai & & + \\
\hline 63. & lkan tupak & Bagarius yarrelli & Sisoridae & & + \\
\hline 64. & Lais & Kriptopterus criptopterus & Siluridae & & + \\
\hline 65. & Lais lamban & Kryptopterus apogon & Siluridae & & + \\
\hline 66. & Tapah & Walago leerii & Siluridae & & + \\
\hline 67. & Ikan bentet & Clarias melanoderma & Siluridae & + & + \\
\hline 68. & Lais putih & Kryptopterus hexapterus & Siluridae & & + \\
\hline 69. & Lais itam & Ceratoglanis scleronema & Siluridae & & + \\
\hline 70. & Riu riu & Pseudiutropius brachycitopterus & Schilbidae & & + \\
\hline 71. & Belut & Ophisternon bengalensis & Synbranchidae & + & + \\
\hline 72. & Buntel & Tetraodon palembangensis & Tetraodontidae & & + \\
\hline 73. & Ikan sumpit & Toxotes microlepis & Toxotidae & & + \\
\hline
\end{tabular}

Sumber: Data primer (2004)

\section{KESIMPULAN}

1. Dari hasil pengamatan jenis-jenis ikan di perairan Sungai Sambujur didapatkan 73 spesies ikan, yang didominansi oleh kelompok ikan famili Cyprinidae.

2. Pada musim kemarau semua jenis ikan tertangkap baik ikan lebak maupun ikan sungai. Pada musim penghujan hanya ikan lebak yang dapat tertangkap.

3. Alat tangkap yang dipergunakan pada musim penghujan jaring insang, untuk menangkap anakan ikan berupa selodok dan sanggi. Pada musim kemarau semua jenis alat tangkap dioperasikan baik di lebak maupun di sungai.

\section{DAFTAR PUSTAKA}

Kottelat, A. M., J. A. Whitten, N. Kartikasari, \& Wiryoatmodjo. 1993. Fresh Water fishes of Western Indonesia and Sulawesi. Jakarta. Indonesia. $221 \mathrm{pp}$.

Welcome, R. L. 1985. River fishery. FAO. Fish. Tech. Paper (262). Rome. 330 pp. 